Vol 12, Issue 2, 2019

\title{
ANTIOXIDANT, ANTIBACTERIAL, AND ANTICANCER ACTIVITY FROM MARINE RED ALGAE GRACILARIA EDULIS.
}

\author{
HEMASUDHA TS ${ }^{1}$, THIRUCHELVI $\mathbf{R}^{1 *}$, BALASHANMUGAM.P ${ }^{2}$ \\ ${ }^{1}$ Department of Bio-Engineering, School of Engineering, Vels Institute of Science, Technology and Advanced Studies, VISTAS, Chennai, \\ Tamil Nadu, India, ${ }^{2}$ Avanz Bio Pvt. Ltd., East Tambaram, Chennai, Tamil Nadu, India. Email: thiruchelvi.se@velsuniv.ac.in
}

Received: 17 September 2018, Revised and Accepted: 30 October 2018

\section{ABSTRACT}

Objective: The marine seaweed Gracilaria edulis was collected from Rameshwaram Mandapam coast. The main objective of G. edulis was to check about the antioxidant, antibacterial, and anticancer activity. The potential use of seaweeds is to prevent colon cancer and leukemia. The crude extract of antioxidant activity was done in methanol and aqueous extract in various concentrations using DPPH assay. The antibacterial activity was analyzed in methanol extract. The antibacterial activity was tested in Gram-positive bacteria (Staphylococcus aureus) and Gram-negative (Pseudomonas) bacteria with various concentration. The anticancer activity was tested against using the breast cancer cell line (MDA-MB231)

Methods: The antibacterial activity was checked by crude methanol extract using Gram-positive bacteria (S. aureus) and Gram-negative bacteria (Pseudomonas) with different concentrations. The antioxidant activity was determined using DPPH radical scavenging assay in various concentrations. The anticancer activity was done using 3-(4, 5- dimethylthiazol-2-yl)-2,5-diphenyltetrazolium bromide (MTT) assay against breast cancer cell line (MDA-MB231).

Results: The antioxidant activity of marine red algae was checked using the stable DPPH radical scavenging assay. The antibacterial activity was analyzed and shows the activity of two different bacteria strain against methanol extract. The anticancer activity was done against breast cancer cell line using MTT assay.

Conclusion: Thus, the result shows that red algae G. edulis has good biological activity, and further it can be carried out in pharmaceutical, food preservatives, and cosmetic purpose.

Keywords: Gracilaria edulis, Antioxidant, Antibacterial, Anticancer.

(C) 2019 The Authors. Published by Innovare Academic Sciences Pvt Ltd. This is an open access article under the CC BY license (http://creativecommons. org/licenses/by/4. 0/) DOI: http://dx.doi.org/10.22159/ajpcr.2019.v12i2.29883

\section{INTRODUCTION}

Marine environment plays an inevitable for their chemical and biological diversity, and therefore it is considered as an extraordinary resource for the discovery of new anticancer drugs. Recent developments in the elucidation of therapeutic action of natural products help us to evaluate for their various potential activity [1]. Seaweeds offer a rich source of bioactive molecules [2]. The seaweed is a diverse and large group of macroalgae. Based on the presence of photosynthetic pigments the aquatic macroalgae organisms which are broadly classified into various types, that is, rhodophyta (red algae), chlorophyta (green algae), and phaeophyta (brown algae). They are grouped according to their unique photosynthetic pigments, which give them their characteristics color and unique properties [3].

There are about 4000 species of red algae found in nature. In Japan and China, the seaweeds are widely used in diet, and it is also used as traditional medicine. Seaweeds are one of the most promising and richest sources of bioactive primary and secondary metabolites. In Asian centuries, the seaweed is used as diet foodstuff commonly [4]. Marine seaweeds or other plants the food with the help of light and oxidizing agent that leads to the formation of free radical and other strong oxidizing agents. Seaweeds are considered as an essential source in the form of bioactive metabolites, in which constituents from the Gracilaria species can be used to treat life-threatening diseases such as acquired immunodeficiency syndrome and cancer [5]. Thus, the study was to assess antibacterial, antioxidative, and anticancer potentialities of $G$. edulis settled along the Mandapam coast of Tamil Nadu.

\section{METHODS}

Collection of sample

The sample Gracilaria edulis (Red algae) were collected from intertidal zone of Mandapam coast (Lat. $9^{\circ} 17^{\prime \prime N}$; Lon. $79^{\circ} 19^{\prime \prime E}$ ) of Gulf of Mannar, southeast coast of Tamil Nadu, India. The collected sample was cleaned with seawater to remove the epiphytes and sand particles. The sample has been packed in a polythene bag and brought to laboratory. Then, the sample was washed with fresh water and shade dried. The shade dried sample is stored and preserved for further use.

\section{Sample identification}

The seaweed was identified and authenticated by Dr. Ganesan, senior scientist, CSIR-Central salts and Marine Chemical Research Institute, Mandapam camp, Ramanathapuram, Tamil Nadu, India [Fig. 1].

\section{Preparation of extract}

\section{Methanol extraction}

The seaweed was collected and dried it for 1 day, after the completion of drying; $50 \mathrm{~g}$ of seaweed is measured accurately and pulverize it gently. After pulverizing, add the seaweed in a conical flask and add $150 \mathrm{ml}$ of methanol to the added seaweed and place it in the orbital shaker for $24 \mathrm{~h}$ at $32^{\circ} \mathrm{C}$ in room temperature. After squeezing, the solvent was taken out, and the extraction liquid is kept ready for the filtration process. The extraction liquid was filtered by using Whatman filter paper. The extracted sample was condensed using Soxhlet extractor at $50^{\circ} \mathrm{C}$ and stored for further use [6]. 


\section{Aqueous extraction}

The seaweed of aqueous extract was dried. After drying, $3 \mathrm{~g}$ of seaweed is measured and pulverize it gently. Then, add $50 \mathrm{ml}$ of distilled water to the added seaweed in the conical flask. The solution was filtered using Whatman filter paper, and the filtered solution was condensed using Soxhlet extractor. The solution was stored in a refrigerator for further [6].

\section{Antibacterial activity}

The antibacterial activity of G. edulis was tested against various Grampositive and Gram-negative strains using agar disc diffusion technique with Staphylococcus and Pseudomonas bacterial culture were smeared in the agar disc is used to see the antibacterial activity. The antibacterial activity was carried out using different concentrations such as $25 \mathrm{uL}$, $50 \mathrm{uL}, 75 \mathrm{uL}$, and $100 \mathrm{uL}$ crude extract of $G$. edulis with the control value of $21 \mathrm{uL}$ Zentamycin was used [6]. These were allowed to dry under aseptic condition and incubated at $37^{\circ} \mathrm{C}$ for $24 \mathrm{~h}$ [7]. The diameters of a clear zone around the discs were measured as antibacterial activity [8].

\section{Antioxidant activity DPPH free radical assay}

The assay for DPPH scavenging activity was described by Ratty et al. [9]. The sample was reacted with the stable DDPH radical in an methanol solution. The reaction mixture consisted of a different concentration of sample and $2 \mathrm{ml}$ of DPPH radical solution $(0.4 \mathrm{mM})$. When DPPH reacts with an antioxidant compound which can donate hydrogen, it is reduced. The reaction mixture was incubated at $20 \mathrm{~min}$ in dark condition. The changes in color (from deep violet to light yellow) were read absorbance at $517 \mathrm{~nm}$ using UV-vis spectrophotometer. The mixture of methanol and sample serves as blank $[10,11]$. The control solution was prepared by mixing methanol and DPPH radicals. The scavenging activity percentage [AA\%] was determined according to formula:-

$$
(\mathrm{AA} \%=[\text { control-sample }] / \text { control } * 100)
$$

\section{Cell culture}

The extracts were tested on McCOY cell. The cancer cell line was collected and grown in Dulbecco's Modified Eagle Modified Eagle Medium (D-MEM) with fetal bovine serum. Cells were seeded in 96-wells and allowed to adhere for $24 \mathrm{~h}$ at $37^{\circ} \mathrm{C}$, with $\mathrm{CO}_{2}$, in an incubator. Then, 1 of it serially diluted samples in the medium were dispensed into the wells of the cell plates and incubated for a further $72 \mathrm{~h}$. After removal of the sample medium, the cells were added with DMEM medium and incubated. After $72 \mathrm{~h}$ cells were fixed with cold $40 \%$ trichloroacetic acid at $4^{\circ} \mathrm{C}$ for $1 \mathrm{~h}$ and washed with water. The absorbance was measured at $492 \mathrm{~nm}$ using a microplate reader [12]. Percentage of dead cells was calculated in comparison to control. The concentration of the extract that inhibition of cells growth was determined in Table 4.

Determination of cell viability (3-(4, 5- dimethylthiazol-2-yl)-2,5diphenyltetrazolium bromide [MTT] assay)

The anticancer activity of drug tested against breast cancer cell line (MDA-MB 231) by MTT assay.

The MDA-MB 231 cells seeded in 96-well microplates $\left(1 \times 10^{6}\right.$ cells/well $)$ and incubated at $37^{\circ} \mathrm{C}$ for $24 \mathrm{~h}$ in $5 \% \mathrm{CO}_{2}$ incubator and allowed to grow $90 \%$ confluence. Then, the medium was replaced, and the cells were treated with the drug at a different concentration of such as 20 , $40,60,80$, and $100 \mu \mathrm{g} / \mathrm{mL}$ and incubated for $24 \mathrm{~h}$. The cells were then washed with phosphate-buffer saline (PBS, pH-7.4) and MTT solution $\left(5 \mathrm{mg} / \mathrm{mL}\right.$ ) was added to each well. The plates were then stand at $37^{\circ} \mathrm{C}$ in the dark for additional 2-4 h. The formazan crystals were dissolved in $100 \mu \mathrm{L} \mathrm{DMSO}$, and the absorbance was read spectrometrically at $570 \mathrm{~nm}$. The percentage of cell viability was expressed as in formula. The concentration that inhibited $50 \%$ of cell growth was referred as $\mathrm{IC}_{50}$ value, which was used as a parameter for cytotoxicity study. The morphological changes of untreated (control) and the cells treated were observed under bright field microscope after $24 \mathrm{~h}$ [13-15].

$$
\text { Cell viability (\%) } \frac{\text { Absorbance of treted cells }}{\text { Absorbance of control cells }} \times 100
$$

\section{RESULTS AND DISCUSSION}

The antibacterial activity of G. edulis was determined in Gram-positive and Gram-negative bacteria. The crude methanol extract shows the good result in antibacterial activity. The zone of inhibition produced by these extracts against the pathogenic microorganisms, and it's measured in diameter (mm). The Gram-positive bacterium has the inhibition zone of $18 \mathrm{~mm}$ in $100 \mathrm{uL}$, and the Gram-negative bacteria have the inhibition zone of $19 \mathrm{~mm}$ in $100 \mathrm{uL}$. Both the Gram-positive and Gram-negative bacteria increased in the concentration of $100 \mathrm{uL}$ were showed in the showed in Table 1 . The in vitro antibacterial activity of seaweeds extracted with methanol and aqueous was showed in various studies $[7,10,16]$. The reviewed articles reported that the antibacterial activities suggest the possibility of the presence of the therapeutic value of seaweed against the bacterial infection. The lowest antibacterial activity was due to the presence of only one of secondary metabolite compound (alkaloid), and the highest antibacterial activity was caused by the activity of any of three phytochemicals such as alkaloid, saponin, and steroids.

The antioxidant activity of the G. edulis extracts was measured on the basis of the scavenging activity of the stable DPPH free radical. It shows the active site of antioxidant in crude methanolic extraction by increasing of inhibition by increasing of concentration. As in the crude aqueous extract, the antioxidant activity that shows slight inhibition increase, with increase of concentration. The crude extract of methanol shows the best result in antioxidant activity and the following table mentioned as Tables 2 and 3. The major role of antioxidant activity is free radical scavenging. The effectiveness of an antioxidant is measured by monitoring the inhibition of oxidation of a suitable substrate. In a biological system, antioxidant effectiveness is classified into two groups that the evaluation of lipid peroxidation and measurement of free radical scavenging ability [17]. The phenolic compounds which have a centre of unsaturation and

Table 1: Antibacterial activity of G. edulis

\begin{tabular}{lllll}
\hline Organism & \multicolumn{4}{l}{ Concentration of the extract } \\
\hline Organism & $20 \mu \mathrm{L}$ & $50 \mu \mathrm{L}$ & $75 \mu \mathrm{L}$ & $100 \mu \mathrm{L}$ \\
Staphylococcus & NA & NA & $15 \mathrm{~mm}$ & $18 \mathrm{~mm}$ \\
Pseudomonas & NA & NA & $10 \mathrm{~mm}$ & $19 \mathrm{~mm}$ \\
\hline
\end{tabular}

The Gram-positive bacteria are Staphylococcus aureus and the Gram-negative bacteria are Pseudomonas species

Table 2: Antioxidant activity by DPPH assay for crude methanol extract

\begin{tabular}{lll}
\hline Concentration $(\boldsymbol{\mu L})$ & Wavelength $(\mathbf{n m})$ & Absorbance $(\%)$ \\
\hline 100 & 517 & 13.361 \\
200 & 517 & 19.08 \\
300 & 517 & 23.43 \\
400 & 517 & 33.93 \\
500 & 517 & 41.99 \\
\hline
\end{tabular}

Crude methanol extract of Gracilaria edulis shows that there is increase in concentration with increase in absorbance value at $517 \mathrm{~nm}$

Table 3: Antioxidant activity by DPPH assay for crude aqueous extract

\begin{tabular}{lll}
\hline Concentration $(\boldsymbol{\mu L})$ & Wavelength $(\mathbf{n m})$ & Absorbance $(\%)$ \\
\hline 100 & 517 & 8.37 \\
200 & 517 & 14.42 \\
300 & 517 & 20.57 \\
400 & 517 & 27.57 \\
500 & 517 & 36.90 \\
\hline
\end{tabular}

Crude aqueous extract of Gracilaria edulis shows that there is increase in concentration increases the absorbance value at $517 \mathrm{~nm}$ 
multi $\mathrm{OH}$ group in their structural moieties, enable them to donate a proton to DPPH radical thereby neutralizing the later $[11,18]$.

The criteria used to categorize the activity of extracts against human breast (McCOY) cell lines based on values of cells as shown in Table 4 and Fig. 2.

The anticancer activity was done and tested against the MDA-MB 231 by MTT assay [19]. The anticancer activity against cancer cell line was inhibited with increased concentration of solvent crude extract. In MDA-MB 231 more cytotoxic effect was observed in methanol extract in $24 \mathrm{~h}$ treatment. It showed that the increased concentration of drug present good toxicity over cancer cell line. It had a maximum of $94.06 \%$ cell viability for $20 \mu \mathrm{g}$ of crude methanolic extract. Similarly, the drug showed its minimum of $37.75 \%$ cell viability of methanol extract. It represents that the increased concentration of drug present good toxicity over MDA-MB 231 [14,16,20] (showed in Table 5).

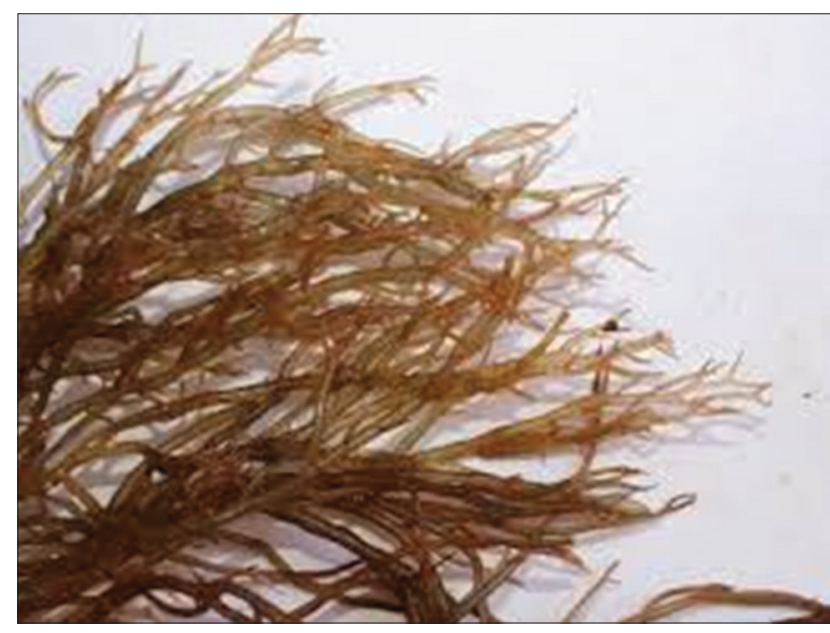

Fig. 1: Gracilaria edulis

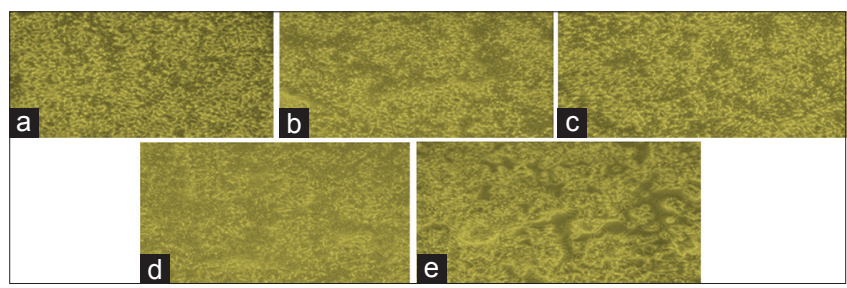

Fig 2: Anticancer activity of G.corticata crude methanol extract of different concentrations. (a) $20 \mu \mathrm{g}$, (b) $40 \mu \mathrm{g}$, (c) $60 \mu \mathrm{g}$, (d) $80 \mu \mathrm{g}$, (e) $100 \mu \mathrm{g}$

Table 4: Cytotoxicity activity of McCoy cancer cell line

\begin{tabular}{ll}
\hline Concentration & \%Inhibition \\
\hline 20 & 95.39 \\
40 & 89.06 \\
60 & 82.04 \\
80 & 72.15 \\
100 & 62.71 \\
\hline
\end{tabular}

Table 5: Anticancer activity of Gracilaria edulis

\begin{tabular}{ll}
\hline Concentrations & \% cell viability \\
\hline $20 \mathrm{ug}$ & 94.06 \\
$40 \mathrm{ug}$ & 80.46 \\
$60 \mathrm{ug}$ & 69.55 \\
$80 \mathrm{ug}$ & 48.97 \\
$100 \mathrm{ug}$ & 37.75 \\
\hline
\end{tabular}

\section{CONCLUSION}

The methanol extract of marine seaweed red algae ( $G$. edulis) shows a good result in various bioactive compounds such as antibacterial activity, anticancer activity, and antioxidant activity (DPPH scavenging of free radicals). It plays a key role in reducing of cancer activity against in vitro study of breast cancer. In previous studies, the red algae species of Gracilaria corticata reported that have numerous bioactive compounds such as pathogens against the antibacterial activity, DPPH assay activity, and anticancer activity [14]. Hence, the marine red algae might have the ability to fight against the cancer pathogen.

Further work is in progress which aimed at the investigation of detailed studies on purification and evaluation of such compounds can take this to large-scale application in pharmaceutical industries.

\section{ACKNOWLEDGMENT}

The author acknowledges the support of Dr. Ganesan, Senior Scientist, Central Salt and Marine Research Institute, Mandapam Camp, Ramanathapuram, Tamil Nadu, India, for authenticating the seaweed. The author also grateful for Dr.P. Balashanmugam Principle Scientist of Avanz Biotech Pvt Ltd., the author would like to extend our thanks to VISTAS and Mrs. R.Thiruchelvi Faculty of Bio-Engineering for the support and guidance.

\section{AUTHORS' CONTRIBUTION}

Hemasudha.T.S, Thiruchelvi.R and Balashanmugam.P conceived and designed the experiment.

Hemasudha.T.S performed the experiment

Hemasudha.T.S and Thiruchelvi.R worked together on manuscript writing.

\section{CONFLICTS OF INTEREST}

There are no conflicts of interests

\section{REFERENCES}

1. Patra S, Muthuraman MS. Gracilaria edulis extract induces apoptosis and inhibits tumor in Ehrlich ascites tumor cells in vivo. BMC Complement Altern Med 2013;13:331.

2. Nithya P, Dhanalakshmi B. Antibacterial activity of methanol extracts from selected seaweed of south east coast of India. Int J Adv Res 2016;2:714-8.

3. Murugan K, Iyer VV. Antioxidant and antiproliferative activities of Marine algae, Gracilaria edulis and Enteromorpha lingulata, from Chennai Coast. Int J Cancer Res 2012;8:15-26.

4. Boobathy S, Soundarapandian P, Prithivraj M, Gunasundari V. Biochemical characterization of protein isolated from seaweed, Gracilaria edulis. Curr Res J Biol Sci 2010;2:35-7.

5. Deepa S, Bhuvana B, Hemamalini S, Janet C, Kumar S. Therapeutic potential and pharmacological significance of the marine algae Gracilaria corticata. Pharm Biol Eval 2017;4:68-72.

6. Abideen S, Sankar MV. In-vitro screening of antidiabetic and antimicrobial activity against green synthesized AgNO3 using Seaweeds. Nanomed Nanotech 2015;6:1.

7. Narasimhan MK, Pavithra SK, Krishnan V, Chandrasekaran M. In vitro analysis of antioxidant, antimicrobial and antiproliferative activity of Enteromorpha antenna, Enteromorpha linza and Gracilaria corticata extracts. Jundishapur J Nat Pharm Prod 2013;8:151-9.

8. Sasikala C, Ramani DG. Comparative study on antimicrobial activity of seaweeds. Asian J Pharm Clin Res 2017;10:384.

9. Ratty AK, Sunamoto J, Das NP. Interaction of flavonoids with 1, 1-diphenyl-2-picrylhydrazyl free radical, liposomal membranes and soybean lipoxygenase-1. Biochem Pharm 1988;37:989-95.

10. Rajakumar R, Singh YA. Preliminary phytochemical and antimicrobial studies on the crude extract of red algae gracilaria edulis against clinical isolates. Eur J Pharm Med Res 2017;4:763-6.

11. Revathi D, Baskaran K, Subashini R. Antioxidant and free radical scavenging capacity of red seaweed Hypnea valentiae from 
Rameshwaram coast Tamil Nadu, India. Int $\mathrm{J}$ Pharm Pharm Sci 2015;8:232-7.

12. Acharya NS, Shah UR, Shah RG, Acharya S, Hingorani L. Evaluation of in vitro anticancer activity of Symplocos racemosa bark against hepatocellular carcinoma. Int J Pharm Pharm Sci 2015;3:384-5.

13. Skehan P, Storeng R, Scudiero D, Monks A, McMahon J, Vistica D, et al. New colorimetric cytotoxicity assay for anticancer-drug screening. J Natl Cancer Inst 1990;82:1107-12.

14. Jayasree P, Thiruchelvi R, Balashanmugam P. Evaluation of antibacterial, antioxidant, and anticancer potentials from marine red algae Gracilaria corticata. Asian J Pharm Clin Res 2018;11:1-4.

15. Gupta PR, Sinha DO, Bandopadhyay RA. Isolation and screening of marine microalgae Chlorella sp. PR1 for anticancer activity. Int J Pharm Pharm Sci 2014;6:517-9.

16. Dayuti S. Antibacterial Activity of Red Algae (Gracilaria verrucosa) Extract Against Escherichia coli and Salmonella typhimurium. InIOP
Conference Series: Earth and Environmental Science; 2018.

17. Arulkumar A, Rosemary T, Paramasivam S, Rajendran RB. Phytochemical composition, in vitro antioxidant, antibacterial potential and GC-MS analysis of red seaweeds (Gracilaria corticata and Gracilaria edulis) from Palk Bay, India. Biocatal Agric Biotechnol 2018;15:63-71.

18. Chakraborty K, Joseph D, Praveen NK. Antioxidant activities and phenolic contents of three red seaweeds (Division: Rhodophyta) harvested from the gulf of mannar of peninsular India. J Food Sci Technol 2015;52:1924-35.

19. Mosmann T. Rapid colorimetric assay for cellular growth and survival: Application to proliferation and cytotoxicity assays. J Immunol Methods 1983;65:55-63.

20. Sheeja L, Lakshmi D, Bharadwaj S, Parveen KS. Anticancer activity of phytol purified from Gracilaria edulis against human breast cancer cell line (MCF-7). Int J Curr Sci 2016;19:36-46. 